\title{
Design of An Expert System for Early Diagnosis of Intestinal Tuberculosis
}

\author{
Zulfikar ${ }^{1, *}$ \\ ${ }^{1}$ Master's Institute of Technology and Business, Pekanbaru, Indonesia
}

\section{Article Information}

Article History:

Accepted by Editor: May 14, 2021

Final Revision: June 11, 2021

Published Online: June 30, 2021

\section{Keywords}

Expert system

Intestinal TB

Fordward Chaining

ADDIE

\section{Correspondence}

E-mail: zulfikar.hc@gmail.com*

\section{A B S T R A C T}

WHO in 2013 released data in the Global Tuberculosis Report that 8.6 million more people were positive for $\mathrm{TB}$, and $15.12 \%$ of them died. One of the causes of death due to tuberculosis is too late to know when it is infected and too late to get treatment. For an initial diagnosis of whether someone has $\mathrm{TB}$, they can immediately go to a hospital or use a computer application that has an expert's ability. This study aims to design an expert system for the early diagnosis of intestinal tuberculosis using the Forward Chaining method. Expert System is one part of Artificial Intelligence that can create a computer program to provide decisions and analysis like an expert or expert in a particular field. The research method used in this study is the Research and Development method with the ADDIE approach. The expert system for early diagnosis of intestinal tuberculosis is designed by making a decision tree diagram to find out the rules needed to diagnose whether a person has intestinal tuberculosis from the symptoms experienced. The formulation of the problem or the rules needed for the initial diagnosis of intestinal tuberculosis in this study was built using the Forward Chaining method. The output of this research is an Expert System in the form of a Stand-Alone application that is built with the Visual Basic Programming Language, which can provide diagnostic results whether a person suffers from intestinal tuberculosis from the symptoms entered into the Expert System Interface.

This is an open access article under the CC-BY-SA license

\section{Introduction}

The development of Information Technology and Computers, both hardware and software are very rapid. Computers have become a major necessity in various aspects of life, both in education, government, economy, health, and several other sectors. One example of direct application of information technology and computers development is artificial intelligence. Artificial Intelligence is widely found today, such as machine learning, vision, robotics, decision support systems, and expert systems. One part of Artificial Intelligence that is easiest to develop is an expert system or expert system. Expert systems can be used to create computer-based experts or experts in certain fields by transferring the knowledge base from an expert or expert. More specifically, an expert system can be interpreted as a process of transferring one's expertise into a computer to solve a particular problem [1].

Many expert systems have been designed to answer very complex human needs, using backward chaining, forward chaining and rule base methods. Some examples of the application of this expert system are to find out what the problem is from car damage using the Forward Chaining method [2]. hen there is 
also an Expert System used in the health sector to diagnose what diseases humans suffer [3]. Furthermore, the expert system can diagnose viral infections in humans using the rule base method [4].

Researchers are interested in designing an expert system to diagnose intestinal tuberculosis based on the data above. Intestinal TB disease was chosen because it is a deadly disease, but many sufferers are unaware that they have been infected and it is too late to get treatment which ends in death. Based on the WHO Global Tuberculosis data, Report in 2013 that there were 1.3 million people who died from this disease of Tuberculosis or TB [5]. Meanwhile, data from the Indonesian Ministry of Health through Disease Control and Environmental Health (P2PL) Indonesia is ranked 4th in the number of TB sufferers [6]. The use of the Forward Chaining method is very suitable for designing an expert system for the diagnosis of intestinal tuberculosis. With the Forward Chaining method, a conclusion is drawn based on the data or facts given or known as data-driven, namely the conclusion process based on the data provided [1].

Tuberculosis (TB) is a disease caused by mycobacteria (Mycobacterium Tuberculosis) which usually attacks the lungs and extra-pulmonary (other than lungs) such as bones, brain, skin, lymph nodes, joint system, intestines, etc. In general, Mycobacterium tuberculosis is rod-shaped with a size of $4 \mathrm{~mm}$ in length and $3 \mathrm{~mm}$ in width and belongs to the category of aerobic bacteria [7]. Tuberculosis is estimated to have developed since 3700 BC. It is based on archaeologists' discovery in Egypt that there are signs of tuberculous spondylitis in the remains of the human spine and mummies [8]. Intestinal Tuberculosis is included in the Extra Severe Pulmonary Tuberculosis category and is deadly. The process of spreading Intestinal Tuberculosis was identified that Mycobacterium tuberculosis enters the lungs and then lodges and spreads through the lymph nodes and blood. The process of spreading through the blood can certainly create opportunities for the development of Mycobacterium tuberculosis outside the lungs such as the intestines and other vital organs.

Common symptoms of Intestinal Tuberculosis include a bloated stomach accompanied by pain, vomiting, diarrhea, irregular bowel movements, weight loss, sluggishness, night sweats and others. Intestinal tuberculosis that is already acute can cause blockage in the intestines and swell in certain parts. The biggest impact of this intestinal tuberculosis disease is not defecating because the intestines have been sticky and united. Intestinal tuberculosis disease sometimes does not give clear symptoms such as pulmonary tuberculosis. For an in-depth diagnosis of Intestinal Tuberculosis, laboratory tests and CT scans are required.

This study aims to create an Expert System that can diagnose in the early stages of Intestinal Tuberculosis by using the Forward Chaining method. The process of early diagnosis of intestinal tuberculosis with this expert system is carried out independently without going to a doctor. The analysis results from this expert system can conclude whether a person suffers from intestinal tuberculosis or not from the symptoms he experiences and suggestions for handling such as direct consultation with a doctor. This research is expected to be able to contribute to the world of health by utilizing information technology and computers.

\section{Method}

The research method used in this study is the Research and Development method [9] with the ADDIE (Analysis Design Develop Implement \& Evaluation) approach [10]. The ADDIE stages are formulated into a research framework that will be carried out in solving the problems that have been identified. The framework of this research is carried out systematically so that the research results do not deviate from the goals that have been set previously. This framework is as shown in Figure 1 below. 


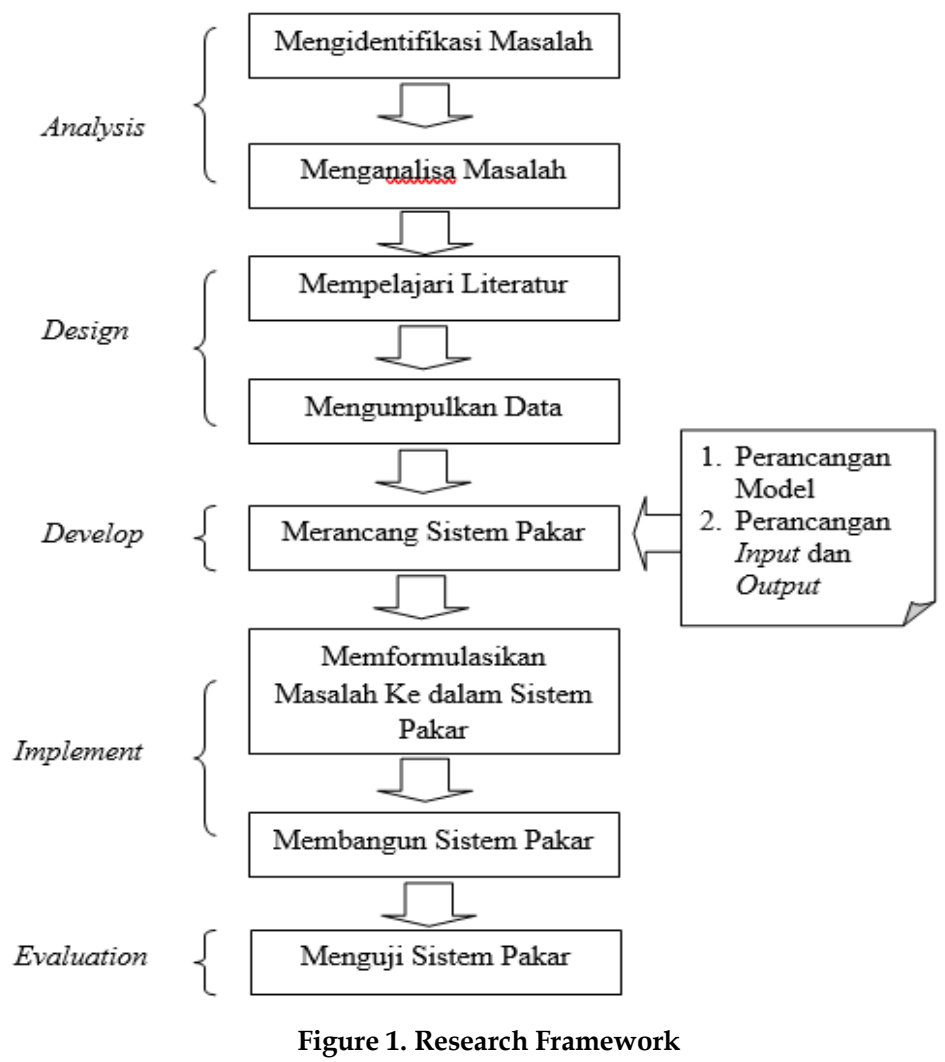

In Figure 1 there are 5 main steps in this research: Analysis - Design - Develop - Implement Evaluation, which is formulated into a framework. There are two main points in the Analysis Stage: Identifying and Analyzing Problems. Identifying the problem is a stage for understanding and finalizing research so that the research objective can be achieved, namely building an Expert System for the initial diagnosis of intestinal tuberculosis from the symptoms experienced by the user. After the problem has been identified, it is necessary to analyze the problem to determine what variables are involved and the solutions for each of these problems. The more problems found in this research, the better the system will be because of the discovery of these problems, several alternative solutions will be obtained. The variables needed in the initial diagnosis of intestinal TB disease, namely: symptoms/causes, classification of intestinal tuberculosis and problem solutions. To support research, studying literature is the most important step to enrich knowledge that will later be entered into the Expert System to produce more accurate results.

The second stage in this research is design. The Design stage is divided into two parts: studying the literature and collecting data. These processes aim to collect data that will be processed in later research. In this study, primary data was obtained from field research, namely by conducting interviews with patients who had suffered from intestinal tuberculosis, specialist doctors and other sources. Furthermore, secondary data is obtained from library research by reading various literature, journals, open books, and other sources. The last time, laboratory research was carried out to develop an expert system for the initial diagnosis of intestinal tuberculosis using the Forward Chaining method.

After the design stage is complete, the next stage is the main part of this research, namely Develop. At this stage, the model's design and the input and output design for the Intestinal TB Diagnosis Expert System are carried out using the Visual Basic Programming Language. After completing the Intestinal TB Diagnosis Expert System after the design process, it enters the next stage, namely Implement. The Implement stage is a stage for testing the rules that have been formulated whether they are already running in the Expert System built. In this implementation stage, the expert system is ready to be used by the user to diagnose intestinal tuberculosis. 
The last stage of this research is Evaluation which is the stage to validate the Expert System that is made to follow the needs that have been set. There are three methods of testing the Expert System that have been built: Manual testing, testing with an expert system, and comparison of manual test results with the Expert System.

\section{Results and Discussion}

The design of an expert system for the initial diagnosis of intestinal tuberculosis in this study uses the forward chaining method. The choice of the Forward Chaining method is because the working principle of the Forward Chaining method concludes the facts given. So the Forward Chaining method is very suitable for finding out whether a patient is affected by Intestinal TB or not from the symptoms he experiences and providing conclusions and solutions from these symptoms like consulting an expert.

The final result of this Expert System is in the form of software whose system works like an expert who can provide a result or conclusion as well as suggestions from a problem experienced by the user. The Expert System will process the symptoms experienced by the user to produce the best conclusions and solutions. To start building an expert system, it takes factual data on TB symptoms and suggestions for handling, as shown in Table 1.

Table 1. Data Facts of TB Symptoms and Suggestions for Handling

\begin{tabular}{|c|c|c|c|}
\hline No & Symptom Variety & Symptoms & $\begin{array}{c}\text { Conclusions and Suggestions for } \\
\text { Handling }\end{array}$ \\
\hline 1 & Respiratorik & $\begin{array}{ll}\text { - } & \text { Cough more than } 2 \\
& \text { weeks } \\
\text { - } & \text { Coughing Blood } \\
\text { - } & \text { Short of breath } \\
\text { - } & \text { Chest pain }\end{array}$ & $\begin{array}{l}\text { If the patient experiences respiratory } \\
\text { symptoms, the patient can be classified as } \\
\text { suspected pulmonary tuberculosis. } \\
\text { Patients are advised to do a physical } \\
\text { examination and bacteriological or } \\
\text { radiological to the hospital. }\end{array}$ \\
\hline 2 & Systemic & $\begin{array}{l}\text { - } \text { Malaise } \\
\text { - Fever accompanied by } \\
\text { night sweats } \\
\text { - Anorexia (impaired } \\
\text { appetite) and weight } \\
\text { loss }\end{array}$ & $\begin{array}{l}\text { If respiratory and systemic symptoms are } \\
\text { experienced by the patient, the patient can be } \\
\text { classified as Positive Suspect Pulmonary } \\
\text { Tuberculosis. } \\
\text { Patients are advised to do bacteriological or } \\
\text { radiological examinations to the hospital. }\end{array}$ \\
\hline 3 & Spesific & $\begin{array}{l}\text { - Abdominal pain and } \\
\text { bloating } \\
\text { - Diarrhea accompanied } \\
\text { by abdominal pain or } \\
\text { irregular bowel } \\
\text { movements }\end{array}$ & $\begin{array}{l}\text { If the patient has respiratory, systemic and } \\
\text { specific symptoms, the patient can be } \\
\text { classified as suspected intestinal tuberculosis.. } \\
\text { Patients are advised to perform special } \\
\text { examinations and other supporting } \\
\text { examinations (CT-Scan, Polymerase Chain } \\
\text { Reaction, BACTEC, Serology, blood tests, etc.) }\end{array}$ \\
\hline
\end{tabular}

\subsection{Knowledge Base and Database Design}

Basis The knowledge base contains knowledge in problem-solving in a particular field. In the rule-based expert system knowledge is represented by using rules: IF - THEN. In IF there are two parts, namely Objects and Values which operators connect. Whereas in THEN there are also two parts, namely Objects and Values which the operator connects. 
The design of this knowledge base consists of facts and rules of intestinal tuberculosis symptoms and suggestions for handling, which will later be matched with a database containing user data, a table of symptoms of tuberculosis, and suggestions for handling and conclusions as in Table 2.

Table 2. Symptoms and Diagnosis of TB

\begin{tabular}{|c|c|c|c|c|c|c|}
\hline No & $\begin{array}{l}\text { Symptom } \\
\text { Code }\end{array}$ & Symptom & $\begin{array}{l}\text { Lung TB } \\
\text { Suspect }\end{array}$ & $\begin{array}{c}\text { Diagnose } \\
\text { Positive Suspect } \\
\text { Lung TB }\end{array}$ & $\begin{array}{l}\text { Intestinal } \\
\text { tuberculosis } \\
\text { suspect }\end{array}$ & $\begin{array}{l}\text { Symptom } \\
\text { Type }\end{array}$ \\
\hline 1 & G1 & $\begin{array}{l}\text { Cough for more than two } \\
\text { weeks }\end{array}$ & $\sqrt{ }$ & $\sqrt{ }$ & $\sqrt{ }$ & Respiratory \\
\hline 2 & G2 & Coughing Blood & $\sqrt{ }$ & $\sqrt{ }$ & $\sqrt{ }$ & \\
\hline 3 & G3 & Short of breath & $\sqrt{ }$ & $\sqrt{ }$ & $\sqrt{ }$ & \\
\hline 4 & G4 & Chest pain & $\sqrt{ }$ & $\sqrt{ }$ & $\sqrt{ }$ & \\
\hline 5 & G5 & Malaise & & $\sqrt{ }$ & $\sqrt{ }$ & Systemic \\
\hline 6 & G6 & Fever with night sweats & & $\sqrt{ }$ & $\sqrt{ }$ & \\
\hline 7 & G7 & $\begin{array}{l}\text { Anorexia (impaired } \\
\text { appetite) and weight loss }\end{array}$ & & $\sqrt{ }$ & $\sqrt{ }$ & \\
\hline 8 & G8 & $\begin{array}{l}\text { Abdominal pain and } \\
\text { bloating }\end{array}$ & & & $\sqrt{ }$ & Spesific \\
\hline 9 & G9 & $\begin{array}{l}\text { Diarrhea accompanied } \\
\text { by abdominal pain }\end{array}$ & & & $\sqrt{ }$ & \\
\hline 10 & G10 & $\begin{array}{ll}\text { Irregular } & \text { bowel } \\
\text { movements } & \end{array}$ & & & $\sqrt{ }$ & \\
\hline
\end{tabular}

From the table the symptoms and diagnosis of TB can be represented in a decision tree diagram and rules or regulations such as Figure 2 and Table 3.

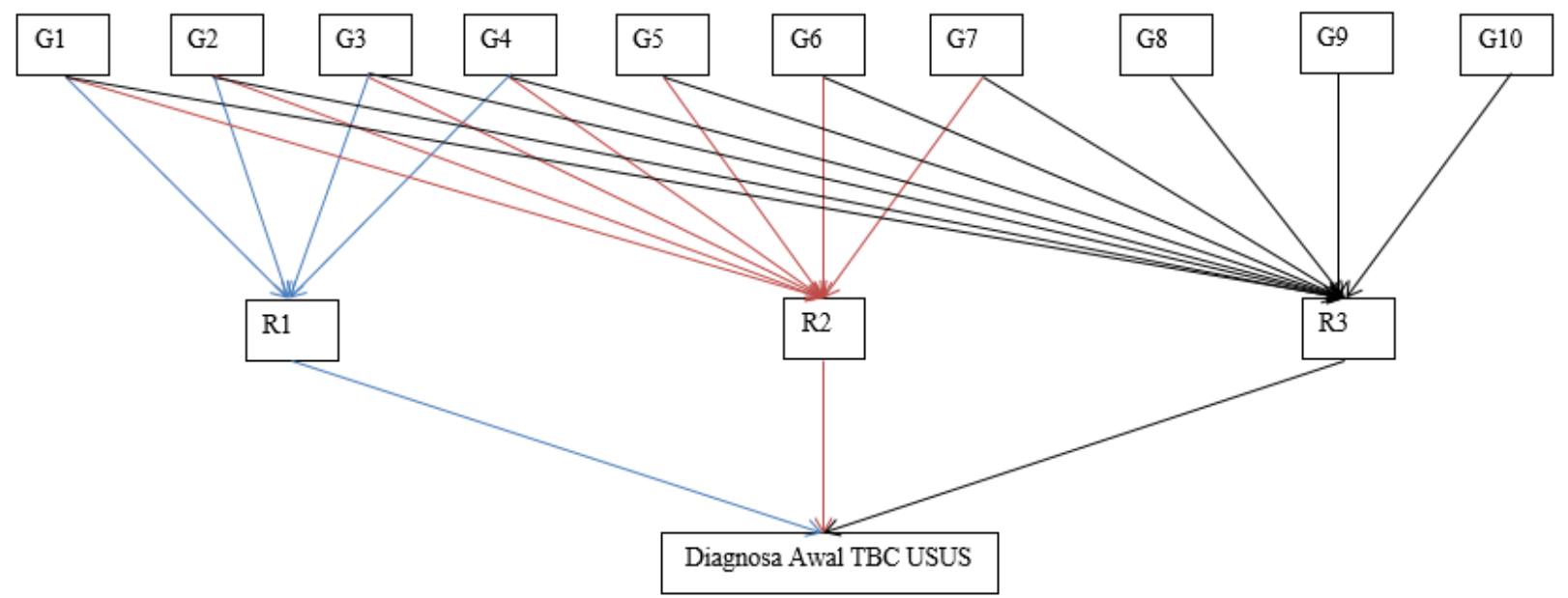

Figure 2. Tree Diagram of the Early Diagnosis of Intestinal TB

Table 3. Rules Used in The Initial Diagnosis of Intestinal TB

\begin{tabular}{lll}
\hline Rules & Conditions and Actions \\
\hline & 1 & $\begin{array}{l}\text { IF G1 is Yes AND G2 is Yes AND G3 is Yes AND G4 is Yes } \\
\text { THEN User is Suspect Lung TB } \\
\text { R1 }\end{array}$ \\
& $\begin{array}{l}\text { IF G1 is Yes AND G2 is Yes AND G3 is Yes AND G4 is No } \\
\text { THEN User is not Suspect Lung TB } \\
\text { IF G1 is Yes AND G2 is Yes AND G3 is No AND G4 is Yes } \\
\text { THEN User is not Suspect Lung TB } \\
\text { IF G1 is Yes AND G2 is Yes AND G3 is No AND G4 is No }\end{array}$
\end{tabular}


THEN User is not Suspect Lung TB

IF G1 is Yes AND G2 is No AND G3 is Yes AND G4 is Yes THEN User is not Suspect Lung TB

IF G1 is Yes AND G2 is No AND G3 is Yes AND G4 is No THEN User is not Suspect Lung TB

IF G1 is Yes AND G2 is No AND G3 is No AND G4 is Yes THEN User is not Suspect Lung TB

IF G1 is Yes AND G2 is No AND G3 is No AND G4 is No THEN User is not Suspect Lung TB

IF G1 is No AND G2 is Yes AND G3 is Yes AND G4 is Yes THEN User is not Suspect Lung TB

IF G1 is No AND G2 is Yes AND G3 is Yes AND G4 is No THEN User is not Suspect Lung TB

IF G1 is No AND G2 is Yes AND G3 is No AND G4 is Yes THEN User is not Suspect Lung TB

IF G1 is No AND G2 is Yes AND G3 is No AND G4 is No THEN User is not Suspect Lung TB

IF G1 is No AND G2 is No AND G3 is Yes AND G4 is Yes THEN User is not Suspect Lung TB

If G1 is No AND G2 is No AND G3 is Yes AND G4 is No THEN User is not Suspect Lung TB

IF G1 is No AND G2 is No AND G3 is No AND G4 is Yes THEN User is not Suspect Lung TB

IF G1 is Yes AND G2 is Yes AND G3 is Yes AND G4 is Yes AND G5 is Yes AND G6 is Yes AND G7 is Yes THEN User is Positif Suspect Lung TB

IF G1 is Yes AND G2 is Yes AND G3 is Yes AND G4 is Yes AND G5 is Yes AND G6 is Yes AND G7 is No THEN User is not Positif Suspect Lung TB

IF G1 is Yes AND G2 is Yes AND G3 is Yes AND G4 is Yes AND G5 is Yes AND G6 is No AND G7 is Yes THEN User is not Positif Suspect Lung TB

$4 \quad$ IF G1 is Yes AND G2 is Yes AND G3 is Yes AND G4 is Yes AND G5 is Yes AND G6 is No AND G7 is No THEN User is not Positif Suspect Lung TB

5 IF G1 is Yes AND G2 is Yes AND G3 is Yes AND G4 is Yes AND G5 is No AND G6 is Yes AND G7 is Yes THEN User is not Positif Suspect Lung TB

6 IF G1 is Yes AND G2 is Yes AND G3 is Yes AND G4 is Yes AND G5 is No AND G6 is Yes AND G7 is No THEN User is not Positif Suspect Lung TB

7 IF G1 is Yes AND G2 is Yes AND G3 is Yes AND G4 is Yes AND G5 is No AND G6 is No AND G7 is Yes THEN User is not Positif Suspect Lung TB

1 IF G1 is Yes AND G2 is Yes AND G3 is Yes AND G4 is Yes AND G5 is Yes AND G6 is Yes AND G7 is Yes AND G8 is Yes AND G9 is Yes OR G10 is Yes THEN User is Suspect Intestinal TB

2 IF G1 is Yes AND G2 is Yes AND G3 is Yes AND G4 is Yes AND G5 is Yes AND G6 is Yes AND G7 is Yes AND G8 is Yes AND G9 is Yes OR G10 is No THEN User is Suspect Intestinal TB

3 IF G1 is Yes AND G2 is Yes AND G3 is Yes AND G4 is Yes AND G5 is Yes AND G6 is Yes AND G7 is Yes AND G8 is Yes AND G9 is No OR G10 is Yes THEN User is Suspect Intestinal $T B$

4 IF G1 is Yes AND G2 is Yes AND G3 is Yes AND G4 is Yes AND G5 is Yes AND G6 is Yes AND G7 is Yes AND G8 is Yes AND G9 is No OR G10 is No THEN User is not Suspect Intestinal $T B$

5 IF G1 is Yes AND G2 is Yes AND G3 is Yes AND G4 is Yes AND G5 is Yes AND G6 is Yes AND G7 is Yes AND G8 is No AND G9 is Yes OR G10 is Yes THEN User is not Suspect Intestinal $T B$

6 IF G1 is Yes AND G2 is Yes AND G3 is Yes AND G4 is Yes AND G5 is Yes AND G6 is Yes AND G7 is Yes AND G8 is No AND G9 is Yes OR G10 is No THEN User is not Suspect Intestinal $T B$

$7 \quad$ IF G1 is Yes AND G2 is Yes AND G3 is Yes AND G4 is Yes AND G5 is Yes AND G6 is Yes AND G7 is Yes AND G8 is No AND G9 is No OR G10 is Yes THEN User is not Suspect Intestinal $T B$ 


\subsection{Inference Engine}

The inference engine contains rules or rules for matching facts with knowledge and the final conclusion from the search. Based on the inference technique used, namely Forward Chaining, the search starts from the facts entered by the user to be compared with IF and rules in the knowledge base. If the facts entered by the user and the IF of the rule in the knowledge base are the same as the facts in the database. Then the rule fires, and as a consequence THEN of the rule is executed, namely the conclusion and solution to the diagnosis of intestinal tuberculosis. When the rule fires, the rule will be added to a new fact in the database.

In this study, there are three rules, namely R1, R2 and R3. The tracing process using the Forward Chaining method is as follows. The R1 rule in the knowledge base is (IF G1 is Yes AND G2 is Yes AND G3 is Yes AND G4 is Yes THEN User is Suspect pulmonary tuberculosis). The Facts in the Database for Symptoms are (G1 G2 G3 G4 G5 G6 G7 G8 G9 G10). While the conclusion is (suspect pulmonary tuberculosis, positive suspect pulmonary tuberculosis, suspected intestinal tuberculosis). If the user enters the symptoms he is experiencing (G1, G2, G3 and G4) and according to the IF of the Rule in the knowledge base, this rule will fire and as a consequence THEN is executed, i.e. the user is diagnosed with suspected pulmonary tuberculosis.

For Rule R2 in the Knowledge Base, namely (IF G1 is Yes AND G2 is Yes AND G3 is Yes AND G4 is Yes AND G5 is Yes AND G6 is Yes AND G7 is Yes THEN User is Positive Suspect Lung TB). The facts in the database for Symptoms are (G1 G2 G3 G4 G5 G6 G7 G8 G9 G10). While the conclusion of the data is (suspect pulmonary tuberculosis, positive suspect pulmonary tuberculosis, suspected intestinal tuberculosis). If the user enters the symptoms he is experiencing (G1 G2 G3 G4 G5 G6 G7) and according to the IF of the Rule in the knowledge base, this rule will fire and consequently THEN is executed, i.e. the user is diagnosed with Positive Suspect Lung TB.

For Rule R3 in the knowledge base is (IF G1 is Yes AND G2 is Yes AND G3 is Yes AND G4 is Yes AND G5 is Yes AND G6 is Yes AND G7 is Yes AND G8 is Yes AND G9 is Yes OR G10 is Yes THEN User is Suspected Tuberculosis Intestine). The facts in the database for Symptoms are (G1 G2 G3 G4 G5 G6 G7 G8 G9 G10). While the conclusion is (suspect pulmonary tuberculosis, positive suspect pulmonary tuberculosis, suspected intestinal tuberculosis). If the user enters the symptoms he is experiencing (G1 G2 G3 G4 G5 G6 G7 G8 G9 G10) and according to the IF of the Rule in the knowledge base, this rule will fire and THEN of the Rule will be executed, i.e. the user is diagnosed with suspected intestinal tuberculosis. If the user enters the symptoms they experience that do not match the existing rules, the system will respond by displaying a message that the user does not meet the criteria for the symptoms of intestinal tuberculosis.

\subsection{Implementation and Testing}

Implementation of the Expert System for early diagnosis of intestinal TB is a stand-alone application consisting of several interfaces in the form of forms that can provide diagnostic results whether a user suffers from intestinal tuberculosis or not from the symptoms he experiences. Figure 3 is a display from the main page of the Expert System for Early Diagnosis of Intestinal TB. 


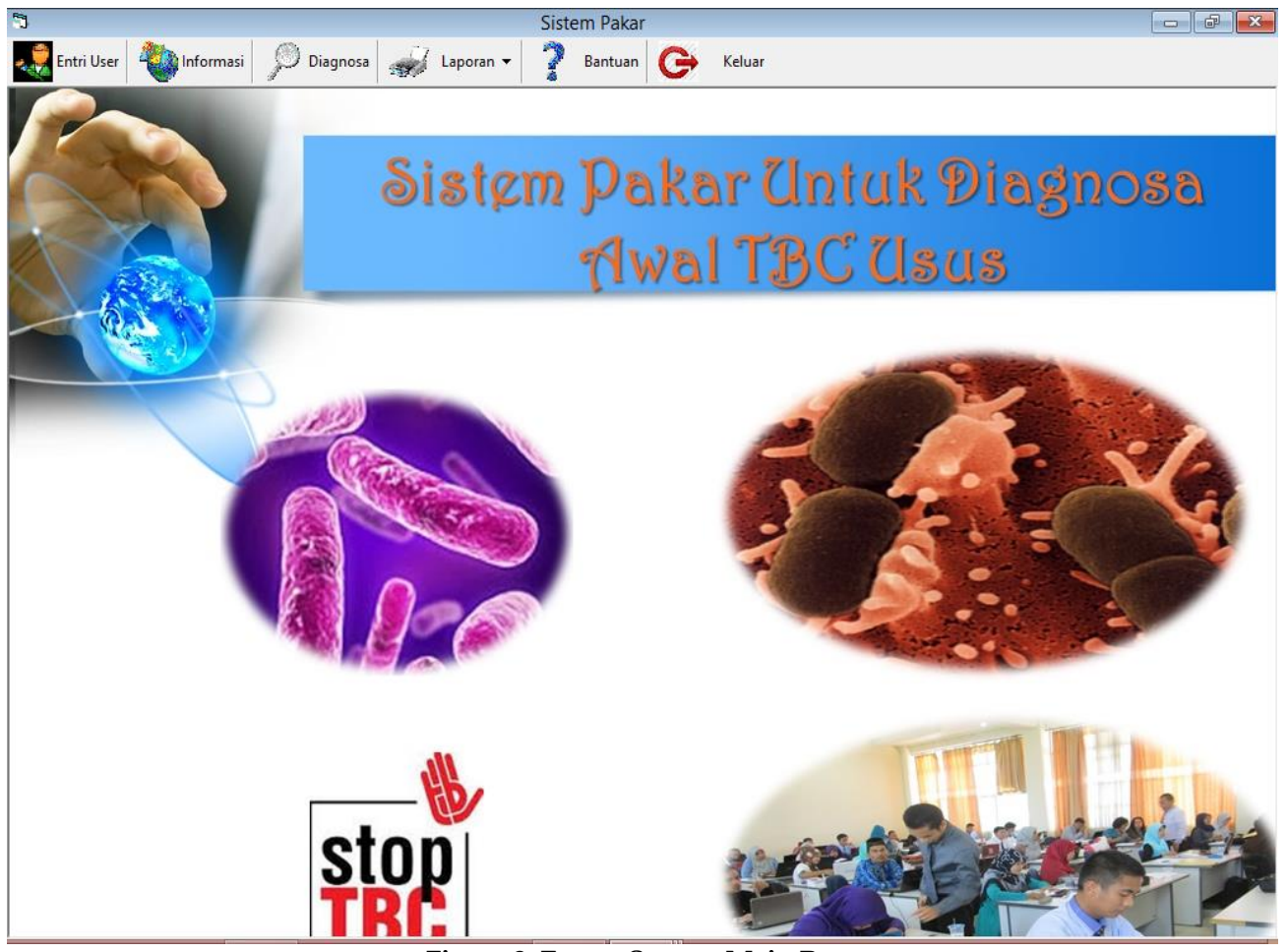

Figure 3. Expert System Main Page

The main page display of the expert system contains a user entry menu bar to enter user or user data, an information menu containing information about tuberculosis in general and intestinal tuberculosis in particular. Next is the diagnosis menu, which is the main menu for the initial diagnosis of intestinal tuberculosis. If the user has made a diagnosis and the results are out, it can be printed in the report menu. Furthermore, a help menu contains instructions for using an expert system for early diagnosis of intestinal tuberculosis for users. At last, there is an exit menu if the user wants to close the application. The diagnostic menu display is shown in Figure 4. 


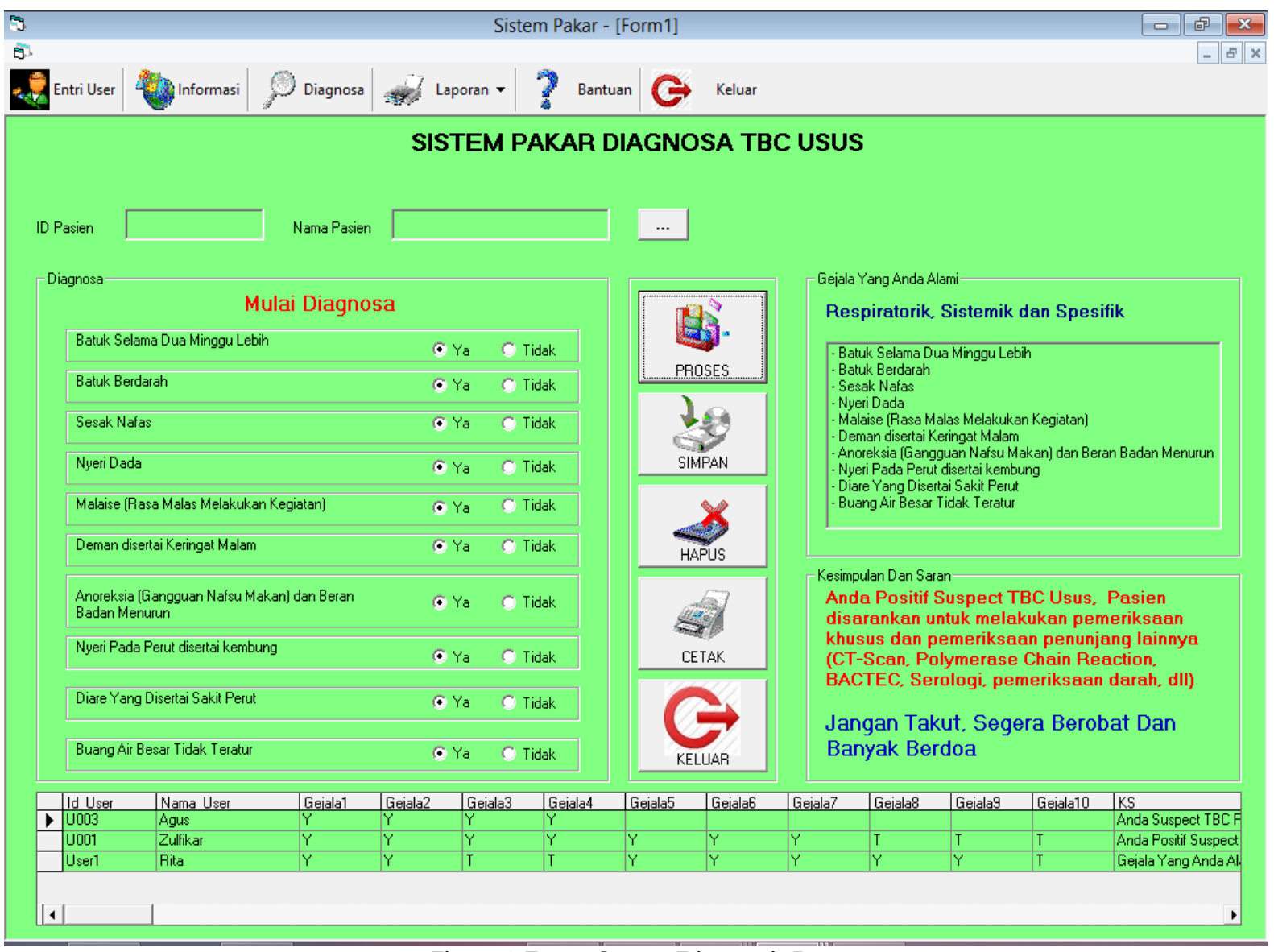

Figure 4. Expert System Diagnostic Page

The diagnostic menu display contains the Id and Name of the Patient or User, Options for Symptoms of the Initial Diagnosis of Intestinal TB, namely Yes or No, which must be filled in by the user. Furthermore, there are conclusions and suggestions from the results of the symptoms that have been entered. To display the diagnostic results report as shown in Figure 5.

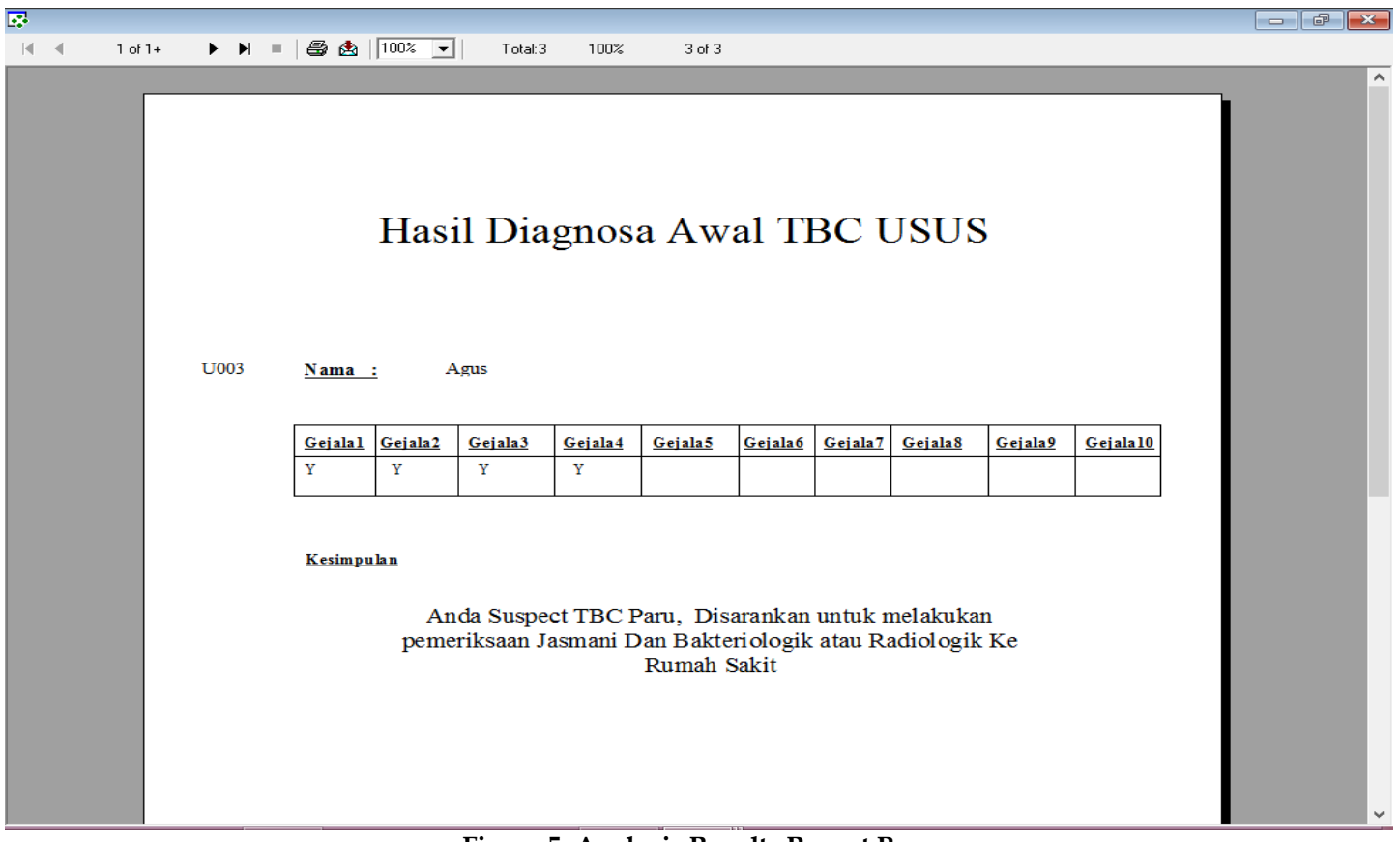

Figure 5. Analysis Results Report Page 


\section{Conclusion}

This expert system is designed by making a decision tree diagram to determine the rules needed to diagnose whether a person suffers from intestinal tuberculosis from the symptoms experienced. The formulation of the problem of early diagnosis of intestinal tuberculosis was built using the forward chaining method. The final result of the Expert System for early diagnosis of intestinal TB is a ready-to-use application that can provide a conclusion whether a person suffers from Intestinal TB or not from the symptoms he or she experiences and treatment suggestions, such as consulting a specialist.

The design of an expert system for the initial diagnosis of intestinal TB disease still has many shortcomings where the final result of this expert system is only an initial diagnosis and treatment solution. If there are parties who want to continue and develop this research for the better, the results can be maximized. The Expert System designed in this study is a stand-alone version that can be used on computers with the Windows operating system.

\section{References}

[1] Putri. P.A, Mustafidah. H, "Sistem Pakar untuk Mendiagnosa Penyakit Hati Menggunakan Metode Forward Chaining," Jurnal Informatika., vol. 1, no.4, pp. 143-155, 2011.

[2] Deepa. S.T, Packiavathy. S.G, "Expert System For Car Troubleshooting," International Juornal For Research In Science $\mathcal{E}$ Advance Technologies., vol.1, no.1, pp.046-49, 2012.

[3] Patra. S.K, Sahu. D.P, Mandal. I, “An Expert System for Diagnosis of Human Diseases," Internasional Juornal of Computer Applications., vol.1, no.13, pp. 71-73, 2010.

[4] Patel. M, Atul. P, Paresh. V, “Rule Based Expert System for Viral Infection Diagnosis," International Journal of Advanced Research in Computer Science and Software Engineering., vol. 3, no.5, pp. 591-595, 2013.

[5] World Health Organization. “Global tuberculosis report 2013” https://apps.who.int/iris/handle/10665/91355, Oct. 21, 2013 [Sep. 12, 2014]

[6] Kementrian Kesehatan Repulik Indonesia, Pharmaceutical Care. Direktorat Bina Farmasi Komunitas dan Klinik Bina Kefarmasian, 2015

[7] Wijaya. M.K.I, "Pengetahuan, Sikap dan Motivasi Terhadap Keaktifan Kader Dalam Pengendalian Tuberkulosis," Jurnal Kesehatan Masyarakat., vol.8, no.2, pp. 137 - 144, 2013

[8] Lyanda. A, "Rapid TB Test," Jurnal Tuberkulosisi Indonesia., vol.8, pp.12-17, 2012

[9] Ade Djohar. M, Metode Penelitian Teknik Informatika. Yogyakarta : Deepublish, 2014, pp. 49-53

[10] Morrison. G.R, Ross. S.M, Kalman. H.K, Kemp. J.E, Designing Effective Instruction. USA : John Wilwy \& Son, 2011, pp. $12-15$ 